\title{
From South Africa to Salt Lake City: Eli Wiggill, the Latter-day Saints, and the world of religion, 1810-1883
}

\author{
Fred E. Woods*
}

\begin{abstract}
This article is a distillation of the autobiography of Eli Wiggill written in 1883. Born in Gloucestershire, England, 1810, his father Isaac Wiggill and mother Elizabeth Grimes, were among the first group of British settlers who arrived in the Cape Colony in 1820 with Eli. This article highlights Wiggill's wide-ranging experiences in southern Africa until his departure to Salt Lake City in 1861. Wiggill vividly describes three decades which include several years as a Wesleyan Methodist missionary in Bechuanaland, mention of the extinction of slavery (1834), the Xhosa wars, as well as his conversion to the Church of Jesus Christ of Latter-day Saints (1858) and his ecclesiastical service as a church leader in Port Elizabeth (1860). Wiggill's narrative also provides an account of his immigration to Utah (1861) as well as his experiences when he lived in Salt Lake City and Kaysville, Utah, during the decade of the 1860s. It further records his return to South Africa as a missionary "to see his friends" in late 1869 until his return in 1873. Wiggill provides an authentic voice which deserves to be heard. His autobiography provides a vivid description of life among the earliest British settlers in the Cape as well as the early beginnings of the Church of Jesus Christ of Latter-day Saints in Southern Africa just over two decades after the Church was organised in upstate New York.
\end{abstract}

Keywords: British Empire; Cape Colony; Latter-day Saint; mission history; Mormons; Salt Lake City; Wesleyan Church; Xhosa; 1820 settlers.

\section{Opsomming}

Hierdie artikel is 'n distillering van die outobiografie van Eli Wiggill wat in 1883 geskryf is. Hy is in 1820 in Gloucestershire, Engeland gebore and sy vader, Isaac Wiggill, en moeder, Elizabeth Grimes, was onder die eerste groep Briste setlaars wat in in 1820 saam met Eli in die Kaap geland het. Hierdie artikel gaan oor die wye verskeidenheid van Wiggill se ondervindinge in suidelike Afrika na tot sy vertrek na Salt Lake City in 1861. Op 'n aanskoulike manier beskryf Wiggill drie dekades waaronder etlike jare as 'n sending van die Weslyaans-Metodiste kerk in

* $\quad$ Fred E. Woods is a professor at Brigham Young University in the College of Religious Education. Dr Woods has lectured extensively in the United States and abroad on the global history of the Church of Jesus Christ of Latter-day Saints with an emphasis on Mormon migration. He is the chief editor and compiler of the Mormon Migration website: https://mormonmigration.lib.byu.edu/

How to cite this article: F.E. Woods, "From South Africa to Salt Lake City: Eli Wiggill, the Latter-day Saints, and the world of religion, 1810-1883", Historia, 64, 1, May 2019, pp 1-22.

http://dx.doi.org/10.17159/2309-8392/2019/v64n1a1

Copyright: (C) The Author(s). Published under a Creative Commons Attribution Licence. 
Betsjoeanaland, die einde van slawerny (1834), die Xhosa-oorloë, asook sy bekering na die Kerk van Jesus Christus van die Heiliges van die Laaste Dae (1858) en sy diens as kerkleier in Port Elizabeth. Wiggill se verhaal verskaf ook 'n oorsig van sy immigrasie na Utah (1861) asook sy ervaringe in Salt Lake City en Kaysville, Utah, gedurende die 1860s. Verder vertel hy van sy terugkeer na Suid-Afrika as 'n sendeling "to see his friends" vanaf laat 1869 tot sy terugkeer in 1873. Wiggill verskaf 'n outentieke stem wat verdien om gehoor te word. Sy outobiografie verskaf 'n aanskoulike beskrywing van die vroegste Britse settlaars se lewe in die Kaap asook die begin van die Kerk van Jesus Christus van die Heiliges van die Laaste Dae in suidelike Afrika, ná slegs twee dekades nadat die kerk ontstaan het in die noordelike dele van New York staat.

Sleutelwoorde: Britse Ryk; Kaapkolonie; Heiliges van die Laaste Dae; sendinggeskiedenis; Mormone; Salt Lake City; Weslyaanse Kerk; Xhosa; 1820setlaars.

The adventurous Eli Wiggill ${ }^{1}$ was born in 1810 in Gloucestershire, England, the eldest son of Isaac and Elizabeth Wiggill. ${ }^{2}$ A decade later, he left with his parents, three siblings, and a number of other British emigrants aboard the Kennersley Castle for southern Africa to embark upon a new life. ${ }^{3}$ Several months later, they landed at the

1. This article is an edited distillation of The Life and Adventures of Mr. Eli Wiggill, found in the Harold B. Lee Library, Brigham Young University, L. Tom Perry Special Collection, MSS 9137, p 1 (hereafter cited as LAEW). This is Wiggill's original, handwritten autobiography, written in 1883 and produced in four different volumes. However, each volume is not referenced throughout this article, because the pages are consistent and each volume is easily identifiable. According to $L A E W$ (p 760), Wiggill wrote his 766-page, four-volume work in the year 1883. The last six pages are in the handwriting of his granddaughter, Susannah Margaret Lowe Dodge. Although it was written in 1883, a comparative study of other nineteenth-century Latter-day Saint missionaries reveals that Wiggill provides us with an authentic voice which sheds light on southern African nineteenth-century history and southern Africa's early contact with the Church of Jesus Christ of Latter-day Saints. The author is currently editing Wiggill's work and plans to have it published in 2020.

2. For a full treatment on the life of Isaac Wiggill and his family, see T. N. Wiggill, The Cotswolds to the Cape: Isaac Wiggill, 1820 Settler (Theo N. Wiggill and Monash University, Victoria, 2012).

3. The plan to have British emigrants depart from their mother country was instituted by the government in order to ease its troubles of "unemployment and social unrest" and at the same time strengthen its position in South Africa (Cape Town) for trading purposes. The strategy included supplying funding for the transport of 4000 British citizens (out of 80000 applicants) from limited resources ( $£ 50000$ ) authorised by the parliament. On this see L. Thompson, A History of South Africa (Yale University Press, New Haven, 2001), pp 52-55. Isaac Wiggill was one of the five percent whose pleas were heard and circumstances accepted. See Isaac Wiggill's letter of 23 October 1819 at http://www.1820settlers.com/, accessed 31 May 2018 (under 1820 Settlers' Letters) for Wiggill's plea to the British government. 
Cape of Good Hope in the early spring of $1820 .^{4}$ About this same time, a fourteenyear-old farm boy from New York named Joseph Smith Jr. visited the woods near his home. There he beheld a divine vision that changed his life and the lives of many others who would eventually embrace the Latter-day Saint (Mormon) faith. Wiggill's travels, half a world away from New York, would also take him to a spiritual realm and cultural sphere that transformed his life and the lives of his family.

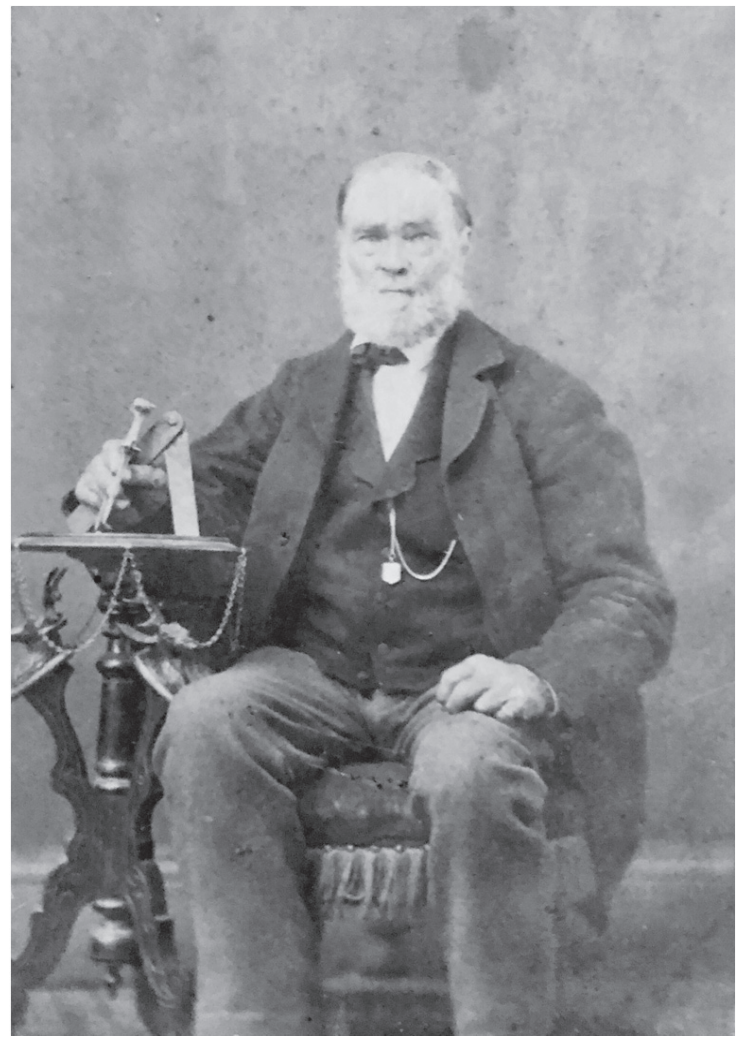

Eli Wiggill, Salt Lake City, c. 1861, courtesy of Mike Lowe

After arriving at Cape Town, the Wiggill's joined other early settlers from Britain and sailed further east, eventually reaching Algoa Bay, now known as Port Elizabeth. The Samuel Bradshaw grouping, which consisted of a dozen settler colonist families, trekked inland via wagons furnished by the British government. They erected a settlement in Lemon Valley, which the newly arrived emigrants renamed New Gloucester, after the township where the Wiggills had come from. ${ }^{5}$ Wiggill

4. LAEW, p 5.

5. LAEW, pp 6-8. 
recalled that upon arrival, these early settlers pitched their tents and kindled fires to "scare away the wild beasts, and the life of a settler was begun". Furthermore, Wiggill provided vivid detail of this new landscape and new hope:

The land over spread by a new race of occupiers; sanguine in their hopes, and eager to develope its capabilities[.] Tribes of barbarians had dwelt in it, but they had gone (driven out by the British tropes) one year or two before settlers came, and the new occupants had to dispute the possession of the soil with inhabitants of other kinds (Wild Beasts) such as Elephants, Tigers and Wolves. ${ }^{6}$

Yet there still remained an eclectic group of people, including the people whom Wiggill referred to as "Kaffirs" (by which he meant the Xhosa people) ${ }^{7}$ and the Dutch transplants. The British would also need to learn to adapt to the rugged terrain, a terrain that stretched them to the limit.

About three years later, Edward King, one of the young traders in the British settlement at New Gloucester, persuaded Wiggill's father to allow Eli to assist him in a variety of labours. These labours included herding the oxen that pulled King's trade wagon through unknown territory. ${ }^{8}$ Wiggill, now a teenager, became a man through the challenging experience. King took advantage of this young novice. Through the experience, Wiggill was exposed to black and white folk, light and darkness, as well as callousness and kindness. In addition to facing the realities of mortality and the demands of manhood, Wiggill would find this strenuous gauntlet tempered by the beauty of nature that surrounded him each day. As he travelled with King through the dense Great Fish River bush region, Wiggill wrote of the unique natural habitat and recorded his early travels, trials, and arduous labour through this magnificent African wilderness:

This dense bush ... I remember it well for I was so tired with that days travel for my limbs aked and hurt me so bad that I could not sleep, and the next morning having to go out from our camp to herd the oxen and that among what is called prickely pears from eight to ten feet high, And child like I began to eat the frute which they bear and not been aquainted with them I got the thorns into my hands

6. LAEW, pp 10-11. The spelling, capitalisation, and punctuation of Eli's autobiography has been preserved throughout this article without the addition of the intrusive sic.

7. The origin of the word Kaffir is based on an Arabic word meaning "infidel" and continues to be an offensive racial slur pertaining to indigenous black African people. The term has also been specifically associated with the Xhosa African people. "Kaffir: Racial Slur Used in Africa to Describe Indigenous African People," 15 November 2012, at http://originalpeople.org/kaffir-racial-slur-used-in-africa-to-describe-indigenousafrican-people/, accessed 31 May 2018. I have quoted Eli Wiggill using this term but personally find it extremely offensive. For an excellent treatment of the indigenous African people and their relationship with white settlers at the time, see N. Mostert, Frontiers: The Epic of South Africa's Creation and the Tragedy of the Xhosa People (Alfred A. Knopf, New York, 1992).

8. LAEW, p 37. 
and mouth and for several days I was in such a state, Well it learnt me a good lesson for I knew how to handle them after that. ${ }^{9}$

King and Wiggill then reached Fort Wiltshire, named after a Colonel Thomas Wiltshire who belonged to a British regiment that helped drive the Xhosa people back just prior to the arrival of the first British settlers in $1820 .{ }^{10}$ Here Wiggill witnessed the interchange between dozens of colonial traders with hundreds and perhaps thousands of Xhosa who gathered to exchange their wares. He described in detail the merchandise and fashion of the Xhosa. ${ }^{11}$

Wiggill also related that what was referred to as the "Fort Wiltshire Fair" which launched the beginnings of international trade among the Xhosa. But the fair turned on the British colonists, as some of the reckless among them smuggled and then sold guns and powder to the indigenous people that surrounded them. This proved to be a fatal blow in the decade that followed with the outbreak of the Xhosa Wars, now known as the Cape Frontier Wars. ${ }^{12}$

From Fort Wiltshire, King and Wiggill returned to Grahamstown before beginning a six-hundred-mile trek to trade with the Dutch in Cape Town. King lied to Eli by telling him his father had given him permission to take Wiggill on this journey. Such deceitful behaviour continued to manifest itself throughout the journey, revealing King's lack of integrity. In addition to this misleading, unstable conduct, the unpredictable weather they encountered on their trek also terrified the young teenager. ${ }^{13}$ Though the expedition was erratic, Wiggill also found it captivating and later recorded his thoughts about the exotic animals encountered on their journey. ${ }^{14}$

As wintertime came on, this travelling pair met with biting snowstorms. Their oxen also strayed away and would have been completely lost had it not been for a "Hottentot"15 whom King employed to find them. The weather eventually became so severe that King made up his mind that they would board with a Dutchman for a couple of months until the severity of the winter had passed. ${ }^{16}$ The warmth and

9. $L A E W, \mathrm{pp} 38-43$.

10. LAEW, $\mathrm{p} 44$.

11. LAEW, pp $46-47,51$.

12. $L A E W, \mathrm{p} 52$. For an overview of these wars, see Thompson, A History of South Africa, pp 70- 109. For an understanding of the issues erupting into conflict within this region, see also M. Wilson, “Co-Operation and Conflict: The Eastern Cape Frontier", in M. Wilson and L. Thompson (eds), A History of South Africa to 1870, (Westview Press, Boulder, 1983), pp 233-271.

13. LAEW, pp 55-58.

14. LAEW, pp $72-73$.

15. The term Hottentot is now considered an offensive and archaic term. The Dutch settlers in South Africa used it with reference to the indigenous Khoikhoi (also spelled Khoekhoe) and San people. The Khoikhoi were pastoralists, while the San were hunter gatherers and lived in the dry, more remote areas such as the Namib and Kalahari Deserts.

16. LAEW, pp 74-75. 
hospitality Wiggill experienced during this winter eased the coldness of the season. He wrote, "The Dutch people ... are very Hospitable[;] if a stranger strays for a week or two at a time they never charge any thing for his board". ${ }^{17}$

Yet as they journeyed further into the wilderness, they again met with hunger and thirst, which was no doubt intensified by the cries of the howling, ravenous wild beasts that surrounded them each night. Driven by intense hunger, King and Wiggill even gnawed on scavenged pieces of bone marrow from the remains of wild game. But the wild game had been dead for so long that the marrow could not satisfy their hunger pains. With time, they found enough water and food to continue, and thankfully, there were intermittent Dutch farmhouses spread along the way to which they retreated; unfortunately, not all the settlers exhibited the same degree of kindness and generosity. ${ }^{18}$

At one of the farmhouses where they lodged, Wiggill saw something he never forgot. The Dutchman with whom they temporarily lodged had a fourteen-year-old slave boy who also had a sister dwelling at a nearby farm to whom the boy would flee. Wiggill witnessed the punishment of this broken adolescent and recorded this brutal, heartless act, which was sketched in his mind:

He was tied to a wagon wheel and the wagon turned on its side so the wheel would turn and every time it turned and the boy came round a man with a large strap in hand and a buckle on the end would give him a cut and the blood would run at every stroak so that the wheel was covered with blood ... then after such a whipping they rubbed salt into his wound then set him to leading oxen at plowing with his hand tied fast to the tow, so that he could not run away. ${ }^{19}$

After witnessing this cruel punishment, the pair moved on and King purchased oxen, cattle, and a horse from a Dutch widow. However, soon thereafter, the horse fled and the cattle and oxen strayed. Instead of assisting with the problem, callous King left Wiggill to search for the animals alone. The two became separated. Wiggill followed King's wagon wheel prints to track him down. ${ }^{20}$ One sympathetic Dutchman whom Wiggill met along the way took compassion on the barefoot teenage boy and provided him with a pair of shoes, which he gratefully received. ${ }^{21}$

King's next irregular enterprise was selling his wagon and oxen for the purchase of horses. Wiggill was not accustomed to riding for long periods and became so sore and tired that he informed King that he simply could not ride any longer. Therefore, the insensitive King instructed the boy to make the arduous travel alone to a distant Dutch farmhouse forty miles away. Fortunately, Wiggill met another kind Dutch family along the way that insisted he remain with them for fear that the

$\begin{array}{ll}\text { 17. } & L A E W, \text { p 76-77. } \\ \text { 18. } & L A E W, \text { p } 78-79 . \\ \text { 19. } & L A E W, \text { p } 77-80 . \\ \text { 20. } & L A E W, \text { p } 81-83 . \\ 21 . & L A E W, \text { p } 87 .\end{array}$


numerous prides of lions in the country would devour him. Thus he stayed with the compassionate family of "Daniel Straidam of the Sweartberg division of the South Africa Cape Colony" for the space of three months. ${ }^{22}$

Eventually, Wiggill crossed paths again with a sickly Edward King, who had been forced to live on rice ants and wild beasts for several months. King promised Wiggill he would take him directly to his parents in the Grahamstown region but again deceived him and turned off selfishly in another direction to collect ostrich feathers to sell. Soon thereafter, the pair came into contact with a Mr William Kittson, who had been told by Wiggill's father that if he ever saw the travelling boy, he should bring him home. Although King tried to dodge Kittson, Kittson was successful in bringing Wiggill back to Grahamstown. As soon as his mother heard of his arrival, she made haste to meet him. ${ }^{23}$

Wiggill returned to live with his family, who had moved to Grahamstown during the year he was away. In the course of his excursion, the boy Eli had transformed into a man. By this time, his father had built a windmill and was living in the lower part of the structure. Soon Wiggill began to assist his father by cutting wood. Regrettably, the mill burned down, and Isaac Wiggill and his family were forced to start over again. Fortunately, kind friends in Grahamstown allowed him to lodge rent-free in an old artillery barracks that had been constructed before the town was laid out. A year later, Isaac was finally back on his feet, and after substantial labour he managed to build another windmill while Eli and his brothers laboured at cutting wood. To supplement the family income, Isaac also made ploughs and wagons and engaged in carpentry work.

Misfortune struck the Wiggill family yet again when Eli's mother died, leaving nine children, with Eli as the eldest at age sixteen. Heartbroken, Eli left home soon thereafter with a determination to learn the craft of wagon making from experienced artisans in Georgetown, some eighty miles away. During the next year, Eli worked for two men who promised him 35 shillings per month but never followed through on giving him any payment. When he returned home, all that he had to show for his efforts were "three tanned sheepskins," which were "just enough to make me a pare of lether Britches ... And one blacksilk Handkerchief". 24

Eli then continued to work with his father, making wagons. Isaac remarried, this time to a woman named Mary Sayers. ${ }^{25}$ Eli, at the age of twenty, married Susannah Bentley, a daughter of one of the 1820 British settlers. At this time, Wiggill launched a wagon business for himself in Grahamstown and had two apprentices working for him. In December 1832, his first child was born, whom he named John. Eli, being of a religious nature, faithfully recorded his infant son's baptism by




Reverend William Shaw, who belonged to the Wesleyan faith. ${ }^{26}$ Two years later, Eli and Susannah had another child. They named her Sarah, but she lived for only about one year. ${ }^{27}$ About this same time, the sixth Xhosa War broke out, a conflict that proved to be a challenge for the British settlers. The war led to the death of Susannah's brother, John Bentley. ${ }^{28}$

Wiggill moved from Grahamstown to a parcel of land in Bathurst he had bought before the war had begun. He remained there for two years, working until about 1837. He was then employed alongside his father to provide five hundred posts for one side of the barracks of Fort Beaufort. Eli then travelled to the Winterberg, where he made wagons, while his brother George ran a blacksmith business. ${ }^{29}$ Then, just prior to returning to Bathurst, Wiggill made an agreement to go to the "Bechuana" country, beyond the Orange River, to work as an assistant minister to Reverend John Edwards of the Wesleyan Methodist Church. ${ }^{30}$ Though he had no official ministerial training, it appears he had a good understanding of the Bible and had been partial to the Wesleyan faith from his youth. Concerning this excursion, Wiggill wrote of the poor timing:

I closed out my wagon business and made preparation to go to Buchanna [Bechuana] Country agreement with Mr. Edwards which was the worst move I ever made for at that time wagon making [was] at its best ... My Brother George continued at the business and became immencely rich ... [as] the Dutch ... must have Wagons and would give any price for them. ${ }^{31}$

26. Reverend Shaw no doubt influenced Wiggill's later decision to enter the ministry. Shaw had come with the Wiggill family amongst the 1820 British settlers a dozen years earlier, and young Eli would certainly have heard his sermons on many occasions. See Wiggill, The Cotswolds to The Cape: Isaac Wiggill, 1820 Settler, p 115.

27. $L A E W$, pp 107-111. Sarah was born 14 October 1834 and died in the district of Fort Beaufort on 5 November 1835. Eli recorded the birth and baptism of each of his children throughout his life.

28. $L A E W, \mathrm{p} 130$.

29. $L A E W$, pp 131-132. The Winterberg is an extensive mountain range running east to west just north of the towns of Adelaide, Bedford, and Fort Beaufort in the Eastern Cape of South Africa. See "Winterberg (Eastern Cape)", available online at https://en.wikipedia.org/wiki/Winterberg (Eastern Cape), accessed 1 June 2018.

30. LAEW, pp 133-136. For a discussion of the commencement of the Wesleyan mission to the Bechuana, including Reverend John Edwards, see J. du Plessis, A History of Christian Missions in South Africa (Longmans, Green \& Co., New York, 1911), pp 176181. For a broader view of Wesleyan missionary labours, see G.G. Findlay and W.W. Holdsworth's five-volume work, The History of the Wesleyan Methodist Missionary Society (The Epworth Press, London, 1921-1924). See L.A. Hewson, An Introduction to South African Methodist (The Standard Press, Cape Town, 1952), pp 1-9, for an overview of the pioneer work of the Methodist ministry in Cape Town as well as on the Cape Eastern frontier, where Wiggill spent most of his life in South Africa. See also J. Whiteside, History of the Wesleyan Methodist Church of South Africa (Elliot Stock, London, 1906), pp 109-115, for an additional treatment of the Methodist Church in the eastern districts of the Cape Colony.

31. LAEW, pp 140-141. 
Wiggill laboured in the ministry for several years in the Bechuana country. Then on 1 May 1842, he received a letter releasing him from his ecclesiastical work at the Thaba Nchu Wesleyan mission station at the close of the year. ${ }^{32}$ Wiggill then travelled with his wife and two children, John and Jemima, to the Winterberg, where his father was living. There he established a farm, built a workshop, and went into business making wagons and doing the work of a blacksmith. However, during this period of time (1843-1845), he was still active in the Wesleyan faith and occasionally preached at the Kat River mission station as well as at Fort Beaufort. ${ }^{33}$

In 1846 there were again rumours of war that ran throughout the frontier settlements, which caused scattered farmers to feel uneasy. Soon the magistrate at Fort Beaufort sent a circular to have the farmers and their families gather to either camps or forts for protection. Soon thereafter martial law was declared in what became known as the War of the Axe, so named, as Wiggill explained, due to a Xhosa who stole an axe. Feeling threatened, Wiggill, his family, and others in his region made haste to a fort known as Post Retief for protection. There for nearly a year, Wiggill worked at his trade of wagon making and performed his military duty. While at Post Retief, another daughter, named Rosanna Maria, came into the Wiggill home. ${ }^{34}$

The following year, Wiggill returned to his farm in the Winterberg, where he remained until 1848. He grew tired of paying rent and went to the Stormberg Mountains, purchasing a home formerly owned by a Dutchman that had never been inhabited. However, there were no farmers in the entire region, so he felt alone in a wilderness that had been burned out for miles around. As a result, Wiggill left just three weeks later. He returned to Bathurst, where his father offered to give him his farm, but it was not to his liking. Therefore, he journeyed on to Fort Beaufort, searching for another place to live, but there too, things did not work out for him. Wiggill returned to the Winterberg, where he leased a parcel of land from his fatherin-law, Mr Francis Bentley, and proceeded to build a house with a shop to make wagons. During this period (1848-1850), his eighth daughter was born, Frances Amelia. ${ }^{35}$

Just before Christmas 1850, Wiggill received another circular from the magistrate warning that a third Xhosa War had broken out and that he must again move into a camp or fort for protection. Therefore, Wiggill and his family returned to Post Retief. Wiggill noted that on Christmas day, "the work of Death and Blood commenced", as both Xhosa and Khoikhoi joined together to pillage and burn the white settlements of the English invaders. ${ }^{36}$

32. $L A E W, \mathrm{p} 235$.

33. LAEW, pp 242-243. Wiggill and his wife also had another daughter, born on 11 October 1843. They named her Margaret Alice. See LAEW, p 247.

34. LAEW, pp 247, 250-252.

35. LAEW, pp 253-260. Frances Amelia was born on 6 May 1849.

36. LAEW, pp 261-267. 
In an attempt to help farmers who were in danger, Francis Bentley (Wiggill's brother-in-law) and Wiggill's son, John, went to check on those gathered at what was known as "Smith's Camp". Unfortunately, John was taken prisoner, which caused much grief to his parents. Fortunately, Wiggill wrote that the captors

... told my son that they did not want to kill or hurt him for they said that they knew his father [Eli Wiggill] well and that he (his father) was a good man and that he had never done them any harm, But that his father had preached to them many a time, and they wanted to save his father to make Wagons for them. ${ }^{37}$

Thus, John's life was spared.

After the war subsided, Wiggill fixed up a burned-out house near Post Retief. It was here that his wife, Susannah, gave birth to another son. They called him Joseph Elijah, whom Wiggill recorded "was Baptized by Rev. Mr. Shepstone, at Kamus Town, which is in the District of Queens Town". ${ }^{38}$ Wiggill reflected that inasmuch as he had no land of his own, he would set off for the new territory of Queenstown.

Eventually Wiggill purchased a city lot in Queenstown for five pounds and commenced to build a house. While building his own house, lodging most of the time on the outskirts of town, he earned money through carpentry work for those who were also eager to build. Referring to the rapid growth of Queenstown, Wiggill wrote: "I never saw any town or village grow so fast, for the people flocked to it from every direction. ... They made a grand rush for what they could get". ${ }^{39}$ Wiggill also noted, "I had all the work that I could do at both making new Wagons and mending old ones". His good work became so well known that people followed him for miles to hire his services. ${ }^{40}$

After about a year, Wiggill exchanged his Queenstown District farm property for a four-room home belonging to his brother-in-law, Francis Bentley, in Queenstown, where he continued wagon making. After living two years in Queenstown, Wiggill received word from the government that all who owned farms must live in them. So he sold his farm to his oldest daughter, Jemima, and her husband, George Ellis, and moved back to his farm to complete a home there. ${ }^{41}$

Several years later, Wiggill's religious life would take a turn. He wrote:

It was about the year 1857 that I heard there was a strange people had come to Africa from America preaching a strange doctrin and was makeing a great [stir] in Cape Town, and Baptizing a few. ... These strange reports went through all the papers from Cape Town to Grahams Town. And [as] I belonged to the Wesleyan denomonation at that time and had been a member for at least thirty years, and 
[as] I said to a friend that they must have been sent of the Devil to try to deceive the very elect, if it was posable, and I believe they were called Mormons which I thought was a very strange name. ${ }^{42}$

Wiggill further noted that he had heard that the Latter-day Saint missionaries had made their way to Fort Beaufort. "There they met with great opposition" and were mobbed, "having brick bats [and] stones and rotten eggs thrown them ... breaking the windows" of a home where they met to preach the gospel. The mob also ran the carriage of one of the missionaries into the Kat River. This missionary, William Walker, was one of the first to preach Mormonism in southern Africa and also converted Eli's brother George. ${ }^{43}$ Walker and his companions, Jesse Haven and Leonard I. Smith, followed on the heels of the preliminary work launched briefly by Elder Joseph Richards in 1852. The missionary trio arrived the following spring (19 April 1853) and preached and published tracts in Cape Town in both English and Dutch. These pamphlets made their way into the hands of Eli's brother George. ${ }^{44}$

In 1855, Elder William Walker travelled from the Winterberg to Queenstown in company with George for the express purpose of meeting Eli, who was then living eight miles from town on a farm in Bongolo. Eli invited his friends to his home, and they listened to Elder Walker as he preached basic principles such as repentance and baptism by the proper authority of God. Eli wrote, "When I heard Walker explain things in the manner he did I could not help [but] believe the truth of it". ${ }^{45}$ Eli

42. LAEW, pp 347-48.

43. Walker's journals were published in Ellen Dee Walker Leavitt (transcriber), Missionary Journals of William Holmes Walker: Cape of Good Hope South Africa, 18521855 (John Walker Family Organisation, Provo, 2003). Walker (p 158) noted herein that while in the Fort Beaufort area on 11 February 1855, he "preached at the home of $\mathrm{mr}$. [George] Wiggils, very good attendance \& the Lord blessed me ... as Mr. Wiggill \& wife had offered themselves as Candidates for Baptism". For a general overview of Latter-day Saint missionary work in South Africa, see E.P. Wright, $A$ History of the South African Mission, 1852-1970, 3 volumes (1977-1986); F.R. Monson, "History of the South African Mission of The Church of Jesus Christ of Latter-day Saints", Master's thesis, Brigham Young University, 1971; and J.H. Buckley, “'Good News' at the Cape of Good Hope: Early LDS Missionary Activities in South Africa", in R.L. Nielson and F.E. Woods (eds), Go Ye into All the World: The Growth and Development of Mormon Missionary Work (Religious Studies Center, Provo, 2012), pp 471-502.

44. LAEW, pp 349-351. Although it has been widely circulated that Jesse Haven, Leonard I. Smith, and William Walker were the first Latter-day Saint missionaries to South Africa, arriving in Cape Town in 1853, this is not entirely correct. The first known Latter-day Saint missionary to preach the gospel in South Africa was actually Joseph Richards, who arrived in Cape Town in 1852 on his way to India to serve a mission there. Writing on 4 August 1852 from Calcutta to his brother S.W. Richards, the president of the European Mission, based in Liverpool, Joseph noted, "I stopped at the Cape one month, and distributed pamphlets, and talked with a number of people, who were glad to hear the truth". He further stated, "It would be a good place for a mission". See "The Work in Hindostan: Extracts of Letters from Elders William Willes and Joseph Richards", Latter-day Saint Millennial Star, 14, 34 (1852), pp 541-542.

45. LAEW, pp 353-356. 
continued to investigate the Latter-day Saint doctrine and purchased pamphlets and books, including the Book of Mormon and the Doctrine and Covenants, which Walker had available for sale. ${ }^{46} \mathrm{He}$ began to see how what the Latter-day Saints were teaching was a restoration of the primitive Christian Church and it could be demonstrated from a careful reading of the Bible. While travelling one day to his home, which was now in Queenstown, Wiggill recalled:

My mind was so full of light and knowlage of the scriptures ... it seemed to me that I could see the meaning of every text in the Bible, so when I got home my Wife said she thought that I had compleatly converted to Mormonism. ${ }^{47}$

Because of this knowledge, Wiggill could not refrain from telling others about what he had discovered. As a result, he wrote:

I got the ill will of some of my own relations most all my religious friends and also my Wife who could not see as I did. It made her feel very bad when she seen all our old friends turn a cold shoulder on me.

As a result, Wiggill noted,

I put all my Books up high on a very high shelf and thought that I would not bother with them for at this time I was a member and a class leader of the Wesleyan Church and local preacher and of corse attended all the meetings.

Therefore, he left his Latter-day Saint literature on the shelf for several weeks yet continued to ponder what he had read. He recorded:

I found that the truth had taken deep root in my heart with what I had read, but I kept very quiet and said but very little ... At last I pulled down my books again and began to investigat them the second time and found them more truth than I had ever seen before in them. 48

In February 1858, Wiggill made a trip to the Winterberg to see his brother George. Then he and George travelled to the Kat River settlement, where a Latter-day Saint elder named John Green, a former Wesleyan, baptised Eli, his wife, Susannah, and two of their daughters, namely Sarah Ann and Margaret, on 1 March 1858. That same day, Wiggill was ordained a priest, which authorised him to also perform baptisms as a member of the Church of Jesus Christ of Latter-day Saints. ${ }^{49}$

46. LAEW, pp 362-363.

47. LAEW, pp 365-366.

48. LAEW, pp 372-375.

49. LAEW, pp 381-382. $L A E W$ ( $\mathrm{p} 400$ ) notes that about three months later (around 1 June 1858), Wiggill was ordained an elder in the church. At this same time, church leaders requested that members worldwide be re-baptised as a demonstration of their willingness to renew their covenants. Wiggill and members of his family did so faithfully, as did other church members of the Queenstown Branch. This action was sparked by what is known as the Mormon Reformation. See P.H. Peterson, "The 
After hearing of Wiggill's baptism, some of his old Methodist friends thought he had been both deceived and deluded by the Mormons. Thus, Wiggill had a number of debates with them, but he noted: "One of my old friends said that there was no use in talking or arguing with me for it seemed to him that I knew the Bible from end to end off my heart." 50 Not only was it known that Wiggill knew his Bible well, but his fame was known throughout the region for his expert artisanship in wagon making. ${ }^{51}$

Wiggill received a steady income in wagon making and also working his farm in Bongolo and was devout in his new religion. However, his life took a turn when a tremendous thunderstorm caused a river to flood his farm "like a Tidal Wave", carrying his wheat away from his field. Therefore, Wiggill recalled:

It began to be well known to me ... [that] I could not stay here long that I must pull up stakes and begin to get ready for the place of the gathering ... and that the Flood had made such Havoc ... I began to think that it was time. ${ }^{52}$

The next move for Wiggill's family would be to migrate to Port Elizabeth, where they arrived 14 May 1860. Soon thereafter, Wiggill was called as the president of the conference region, and his dear friend Henry Talbot was appointed president of the local branch (a local Latter-day Saint congregation), serving under Wiggill's ecclesiastical supervision. ${ }^{53}$ Wiggill wrote that after he was settled in, he

... took charge of the Branch which consisted of about thirty to forty members ... [and] held meeting in Mr. Talbot's house, twice on Sunday and once through the week, and by paying strict attention to our duty ... visiting the sick, and also attending to daley labour. ${ }^{54}$

After nearly a month, the time came for the Wiggill and Talbot families to depart for Utah. At this time Salt Lake City was considered the Mormon Mecca and for devoted converts, it was their duty to gather with the faithful as soon as possible. Concerning their departure, Wiggill wrote of the monumental occasion:

On the twenyeth day of Feb 1861 we bid farewell to the [Port Elizabeth] Branch of the Church where I presided over for about eleven months and also to Algo Bay, And went on board the Bark Race Horse, commanded by Captain John Searles. First myself Wife five children two sons and three Daughters, my Son in

Mormon Reformation of 1856-1857: The Rhetoric and the Reality", Journal of Mormon History, 15 (1989), pp 45-63, for more information on this topic.

50. LAEW, pp 383-384. At this time, Wiggill sold his property in Queenstown and made the decision to live on his farm in Bongolo, a distance of about eight miles.

51. LAEW, p 387.

52. LAEW, pp 420-422.

53. $L A E W, \mathrm{p} 425$.

54. LAEW, p 426. 
law George Ellis Wife and three children, Mr. Henry Talbot Wife and one child making in all thirty two souls. ${ }^{55}$

One of the passengers was a small black African boy about six years old named Gobo Fango. Wiggill noted that the Henry Talbot family had taken the boy in at the time of a great famine (1856-1857) resulting from a false prophecy that required the killing of cattle by a young Xhosa girl named Nongqawuse. ${ }^{56}$ The Talbot family had become so attached to the boy that they took him to America with them. Wiggill noted that Captain Searles assigned Gobo as the feeder of ten sheep the captain had brought on board for food during the voyage and told the young boy that he would read the palms of his hands to see if he had fed the sheep or not. ${ }^{7}$

55. LAEW, pp 444, 436, indicates that the Race Horse was an American vessel that sailed out of Boston. It was primarily a cargo vessel, which explains why there was such a small number of passengers, consisting primarily of the Wiggill and Talbot families. The Mormon Migration website, compiled and edited by F.E. Woods, notes that there were actually 37 passengers on board the Race Horse. On this see "Port Elizabeth to Boston: 20 February 1861 to 19 April 1861", available at https://mormonmigration.lib.byu.edu/mii/voyage/

318? dateFrom $=\&$ scandinavia $=$ on $\&$ date $\mathrm{To}=\& \mathrm{mii}=$ on $\&$ sweden $=0$ on $\&$ netherlands $=0 \mathrm{on} \& \mathrm{v}$ oyage $=$ on \&europe $=$ on\&account $=$ on\&query $=$ race+horse \&passenger $=$ on, accessed 1 June 2018.

56. A personal document in possession of the writer, titled "Henry James Talbot and Descendants" indicates that during the period of famine caused by "the Cattle Killing Delusion, [there were] starving natives by the thousand[s] ... At this time a native woman with a babe in her arms, appeared at the Talbot home half-starved, and told them she had abandoned an older child back along the road. They rescued the child, Gobo Fango, and he became one of the family". Concerning the cause of the famine and the repercussions, see J.B. Peires, The Dead Will Arise: Nongqawuse and the Great Xhosa Cattle-Killing Movement of 1856-7 (Ravan Press, Johannesburg, 1989).

57. LAEW, pp 445, 448-449. According to his last will and testament, given the day before his death, Gobo lived 25 years after arriving in Utah, passing on 10 February 1886 at the age of 32. He continued to herd sheep during the remainder of his life in Utah and Idaho. Though a murder trial was held for a local cattleman in conjunction with Gobo's death, no conviction resulted, as race seemed to play a role in this affair. While there is no record of him being baptised into the Church of Jesus Christ of Latter-day Saints, his will stipulated that after designating money for his friends, the remainder of his assets be given "to help build the temple in Salt Lake City Utah". (His will is located at the Cassia County Records Office in Burley, Idaho.) For an overview of the life and untimely death of Gobo after he arrived in Utah, see H.D. Garrett, "The Controversial Death of Gobo Fango", Utah Historical Quarterly, 57, 3 (1989), pp 264272. 
Not long after the vessel embarked from Port Elizabeth, seasickness set in for the entire company. Wiggill vividly remembered the ocean crossing, noting, "I was sick more or less all the voige[.] I could not bare the smell of cooking and had not appitite to eat anything." ${ }^{8}$ However, the small company apparently got along well with the crew, and the voyage was generally pleasant, notwithstanding the seasickness. In fact, Wiggill recalled, "our evening[s] used to be spent in dancing singing and playing music which made the time pass very agreeable, and very often the Captain would prevail on the girls to sing for him". ${ }^{59}$ Notwithstanding the seasickness and a two-day storm, Wiggill noted, "We got along first rate". ${ }^{60}$

The company arrived in Boston Harbour on 19 April 1861 after a voyage of about two months. As soon as the pilot came on board, he "brought papers and also the news that the [Civil] War had broke out in the United States between the North and the South". ${ }^{61}$ Their arrival could not have been at a more tumultuous time in America, but assistance from the Latter-day Saint emigration agent, Nathaniel V. Jones, concerning arrangements for overland travel and the support of a branch in east Boston no doubt brought welcome relief. Yet the local branch was surprised to learn that the incoming Saints from South Africa were white rather than black and remarked after visiting with the Latter-day Saint passengers newly disembarked from the Race Horse, "Why these people are like ourselves". ${ }^{62}$ The South African Saints stayed in a rented house in Jersey City while they waited for other Latter-day Saint emigrants to arrive on the East Coast. Nearly a month later, they received word that they were to travel to New York, as a ship of Saints was coming in. The combined group of Saints would then travel by rail from New York via Chicago to the wagon outfitting station at Florence, Nebraska. ${ }^{63}$

Concerning the rail travel, Wiggill wrote of an interesting situation involving Gobo Fango during this period of conflict:

While waiting at Chicago for a change of Cars and as the War had commenced about Slavory, Mr. Talbot having the little Kafir boy ... some Collard men happened to spy the little fellow in the Car ... determined to take him away[,] they accusing us of takeing him into Slavoury ... and caused great disturbance but they did not get him for a Lady of the Company hid him under her brinoline [crinoline?] and they surched through the Cars but could not find him, so that after that he was kept concealed as much as posable and put girls Cloaths on him. ${ }^{64}$

58. $L A E W, \mathrm{p} 446$.

59. $L A E W, \mathrm{p} 449$.

60. LAEW, pp 452-454.

61. LAEW, p 454. The Civil War had begun just one week earlier, when Confederate forces in South Carolina attacked Fort Sumter.

62. LAEW, pp 456-457.

63. LAEW, pp 457, 459-460.

64. $L A E W, \mathrm{pp} 460-461$. The American Civil War era was also tumultuous for all incoming European Latter-day Saints who crossed the Atlantic and disembarked on the East Coast. For more information on the challenges faced by these incoming Latter-day 
Soon after arriving in Florence, church leaders organised the incoming Saints into companies. The South African Saints formed an independent company, as they purchased their own wagons in Florence. Some additional hitching also took place. Wiggill wrote, "While I stayed at Florance, two of my Children were married[;] my Son Jeremiah married one of Mr. Talbots Daughters, and my Daughter Margaret was married to Mr. Talbots Son Thomas". 65 These combined families and others from the Race Horse voyage received assignments to travel in the Homer Duncan company. Wiggill recalled that Duncan designated Henry Talbot as the company chaplain, and noted that the company left Florence towards the end of June $1861 .{ }^{66}$ Official church records note that the Duncan company consisted of 264 individuals in 47 wagons and departed on 25 June, arriving in Salt Lake City on 13 September $1861 .{ }^{67}$

Upon arriving in the Salt Lake Valley, the Wiggill family stayed with Duncan's family for about a week, until he found a small house locally in the Seventeenth Ward. ${ }^{68}$ Here he stayed near the west end of Salt Lake City, "near the Jordan River," until his wife complained about the dampness of the spring weather and desired to migrate further north to Kaysville, where some of their family had settled. ${ }^{69}$ However, after a three-year stay in Kaysville, Wiggill returned to Salt Lake City, where he continued his trade as a wheelwright. ${ }^{70}$

In 1867, Wiggill inherited his deceased father's estate. With this money, he purchased a half lot for $\$ 450.00$ and hired a man to build a house on it. ${ }^{71}$ Yet soon after the home was finished and his garden was planted, the grasshoppers destroyed his crops and trees, and worst of all, his faithful wife, Susannah, died on 29 August $1869 .{ }^{72}$ Feeling lonely, Wiggill determined to marry just two months later. He selected a woman who had been a widow for seven years, whom he had known both in South Africa as well as in Salt Lake City. She accepted his proposal, and they were married at the end of October. ${ }^{73}$

Saint immigrants and overland emigrants, see F.E. Woods, "East to West through North and South: Mormon Immigration to and through America during the Civil War", BYU Studies, 39, 1 (2000), pp 7-29.

65. $L A E W$, pp 465-466. These families and their many descendants have remained closely intertwined since the mid-nineteenth century.

66. LAEW, $\mathrm{p} 467$.

67. "Homer Duncan Company (1861)", available at https://history.lds.org/overlandtravel/ companies/43/homer-duncan-company-1861, accessed 1 June 2018. In LAEW (pp 466-485), Eli provided an account of the overland crossing.

68. LAEW, pp 485-486.

69. $L A E W, \mathrm{p} 490$.

70. LAEW, $\mathrm{p} 495$.

71. LAEW, pp 496-497.

72. LAEW, pp 497-498.

73. LAEW, p 503. 
Soon thereafter, Wiggill's son-in-law, William Lowe decided he wanted to go to South Africa with his wife, Frances Amelia, as well as with their baby daughter named Susie. Lowe also invited Wiggill to come along, who had apparently introduced his daughter to Lowe. ${ }^{74}$ Wiggill consulted with his new wife, and she said it would be fine, as she had four sons who were able to support her in his absence. ${ }^{75}$ After visiting family in Kaysville, on 14 December 1869, they left by train for the Ogden depot, ${ }^{76}$ just months after the completion of the transcontinental railroad. They arrived in New York on 5 January $1870 .{ }^{77}$ After searching through the newspaper, Lowe found a freight vessel bound for Cape Town and paid for passage at $\$ 25.00$ per head. They embarked on January 19 with Captain William Amos as the only passengers on the bark Deadorous (Deodorus). ${ }^{78}$ Eli noted that after a voyage of 64 days they entered Table Bay and anchored on 24 March $1870 .{ }^{79}$ After a brief visit at the Cape, Wiggill and his family went aboard a steamer that took them to Algoa Bay and landed in Port Elizabeth on 3 April $1870 .{ }^{80}$

After landing, they sought assistance in finding wagons, which could convey them to the Queenstown region to see family and friends. Fortunately, one of Wiggill's friends in Port Elizabeth spotted a Wiggill wagon, providing a link that led Eli to make contact with the son of his brother Henry and arrange for free transportation. ${ }^{81}$ Subsequent meetings with family and friends brought joy to Wiggill, and seeing the vicinity of his boyhood, the burial place of his mother, and the region where his father once lived, proved nostalgic. ${ }^{82}$

Though not stated in his autobiography, Wiggill's return to South Africa was considered a mission, and a formal report was drawn up upon his return to Utah. In a church mission report dated December 1873, Wiggill wrote, "Left Salt Lake City 12th December on a mission to South East Africa ... to see friends." Among other things, he noted in his handwritten report the following:

Stayed in cape town one week[;] found several there that was in the church[;] preached to them what best I thought and they were glad to see me. ... One of my

74. In 2007, M.T. Lowe wrote and published a book titled African Eden: The Lowes of South Africa, which provides a history of the roots and branches of the Lowe family and their connection to South Africa. It also contains useful information regarding the link with the Eli Wiggill family and some wonderful images. Herein (p 240) Lowe explains that Eli, a wagon maker, and William, a blacksmith, met as a result of their employment at Naylor Brothers, a blacksmith and wagon making business. This relationship led to William meeting Frances Amelia, William's future wife and the daughter of Eli.

75. LAEW, pp 503-504.

76. LAEW, pp 505-506.

77. $L A E W, \mathrm{p} 511$.

78. $L A E W, \mathrm{p} 514$.

79. $L A E W, \mathrm{p} 519$.

80. LAEW, p 534.

81. LAEW, pp 535-538.

82. LAEW, pp 547-560. 
brothers died while I was there. I preached to him faithfully before he died. ... Baptized one man by the name of Cook. Stayed three years in Queenstown and neighborhood, preached to them \& when I came back I came by the Diamond fields ${ }^{83}$ to cape town[;] stayed two months and visted all that was enquiring after the gospel[;] what few faithful brethren are there are too poor to come out[;] some of them have been there 20 years. Left cape Town for home March 11th 1873, crossed the water which took 62 days to Boston[.] Arived from Boston to Salt Lake 26th of May 73. Absent about 3 years and one half, Eli Wiggill. ${ }^{84}$

Upon arriving back at the Ogden, Utah, train depot, Wiggill met two of the church apostles, Elders John Taylor and Wilford Woodruff. Wiggill wrote:

They knowing that I had just come from off a mission told me that I should have come all the way for half Fare but I did not know it at the time I payed my fare in Boston ... which was the 25th of May being away from my home a little over three years. ${ }^{85}$

Upon arrival in Salt Lake City, Wiggill hired a wagon to take him to his home in the Tenth Ward. He was so surprised at the changes that had taken place that his house was a bit difficult to locate. His autobiographical account concludes: "I soon found the House and had my Luggage unloaded and discharged the man with his wagon." 86

Following this final sentence from the hand of Wiggill, the record notes:

This is as far as the history of his life was written by my Grand Father Eli Wiggill in the year 1883. Soon after this he took ill and the history was never completed. So I take great pleasure in writing a short sketch of the last years of his life. ${ }^{87}$

The additional six pages following Wiggill's 760-page autobiography were written by Susannah "Susie" Margaret Lowe Dodge, a granddaughter of Eli. The daughter of William Lowe and Frances Amelia Wiggill, Susie was but a babe at the time she and her parents left for Cape Town in December 1869 with Eli. ${ }^{88}$ Among

83. At this time there was a rush for diamonds, and Wiggill went with his son-in-law William Lowe, his brother Elijah, his nephew Francis, and a few others who had formed a company to mine in the Vaal/Harts River area. See LAEW, p 600.

84. Church History Library, Salt Lake City, Eli Wiggill Missionary Report, December 1873, MS 6104, folder 23.

85. LAEW, $\mathrm{p} 758$.

86. LAEW, $\mathrm{p} 760$.

87. $L A E W, \mathrm{p} 760$.

88. Church History Library, Salt Lake City, "Eli Wiggill History 1810-1884", MS 23753, p 82. This document, referring to the autobiography of Eli Wiggill (also abbreviated as $L A E W$ ), notes, "The remainder of this book was written by Mrs Susie Dodge, granddaughter of Eli Wiggill, and the baby whom he mentions as going to Africa with them in 1869-1870". This history was taken from a transcript produced by Leda Dawson McCurdy in 1975, based on the handwritten account of the autobiography of Eli Wiggill, edited by Reva Marchant in 2000. Although it contains useful information, it also has factual errors, which the author plans to correct in a forthcoming edition of 
other things, Susie described how his wife joined the Reorganized Church of Jesus Christ of Latter Day Saints after Wiggill came home. The couple separated, and Wiggill moved in with his son Jeremiah.

In 1874 he married a Mrs Hammer. He continued to do some carpentry work in the summer and spent the winter reading and writing. Finally, on 13 April 1884, Eli Wiggill passed away. Susie had this to say about his passing:

\begin{abstract}
Deeply regretted by his family and friends. He was a true and faithful Latter-Day Saint and died in hope of a sure Resurrection. ... At his request his body was brought to Kaysville and laid in the cemetery beside his wife Susannah. ... Several speakers testified to his life and character. Brother [Henry] Talbot speaking of their friendship, began as boys in the far away land of Sunny South Africa where they both heard and accepted the gospel travelling from there to Utah in the same Company. ${ }^{89}$
\end{abstract}

Thus ended the life and adventures of Mr Eli Wiggill, who was transplanted from South Africa to Salt Lake City after embracing the message of Mormonism.

\title{
Epilogue
}

The Life and Adventures of Eli Wiggill is an important addition to a serious study of nineteenth-century history in southern Africa. It is also timely that on the eve of the bicentennial commemoration of the British settlers' arrival, this vivid account should surface. In addition, it provides an early look at Latter-day Saint missiology in its earliest period in southern Africa which has not been published in an academic journal in this region. Eli Wiggill was a thoughtful record keeper who not only provides a marvellous view of the open landscape of southern Africa, but who was also a truth seeker who was determined to take seriously the biblical injunction to "prove all things; [and] hold fast that which is good". ${ }^{90}$

"The Life and Adventures of Eli Wiggill", which will include annotations and corrections to Wiggill's autobiography.

89. $L A E W$, pp 761-766. In a letter written by Ann Hammer Wiggill to Henry Talbot, less than a month after Eli passed away on 13 April 1884, Eli's wife explained to his friend Henry Talbot, "He had a longing desire to live and do the work in the Temple, for his dead friends ... [but] that someone else would have to do that work for him, for he always felt he never would recover". Church History Library, Salt Lake City: Ann H. Wiggill to Henry Talbot, 6 May 1884, inserted with the autobiography of Eli Wiggill, MS 8344. Latter-day Saints do proxy ordinance work in temples for their loved ones who are deceased. This doctrine was taught by the Apostle Paul in 1 Corinthians 15:29.

90. Holy Bible, I Thessalonians 5:21. 
Wiggill's autobiography not only provides information about the early Latterday Saint missionaries in southern Africa, but also provides an account of how these missionaries (elders) proselytised during this era. For example, Eli explained that one of the early missionaries (William Walker) preached basic principles of the Gospel through the Bible such as repentance and baptism by divine authority. It is also evident from Wiggill's record that Eli purchased Latter-day Saint pamphlets and books which Walker had for sale which taught Wiggill about the restoration of the primitive Church of Jesus Christ. In addition, it provides us with a look the organisation and operation of the first branch of the Church of Jesus Christ of Latterday Saints in Port Elizabeth and captures the most detailed account of a Latter-day Saint convert from southern Africa just five years after the establishment of the Cape of Good Hope Latter-day Saint mission. In addition, it documents his immigration to Utah and his return to southern Africa as a missionary a decade later.

It is an authentic voice which deserves to be heard. It provides a look at the early beginnings of the Church of Jesus Christ of Latter-day Saints in Southern Africa just over two decades after the Church was organised in upstate New York in 1830. What began with a few members, mushroomed with time and today there are nearly 66000 Latter-day Saints who belong to 183 congregations in South Africa. ${ }^{91}$

\section{REFERENCES}

Alston, B.T., "The Cumorah Baseball Club: Mormon Missionaries and Baseball in South Africa", Journal of Mormon History, 40, 3 (Summer 2014).

Buckley, J.H., "'Good News' at the Cape of Good Hope: Early LDS Missionary Activities in South Africa", in R.L. Nielson and F.E. Woods (eds), Go ye into All the World: The Growth and Development of Mormon Missionary Work (Religious Studies Center, Provo, 2012).

Church History Library, Salt Lake City, "Eli Wiggill History 1810-1884”, MS 23753.

Du Plessis, J., A History of Christian Missions in South Africa (Longmans, Green \& Co., New York, 1911).

Findlay, G.G., and Holdsworth, W.W., The History of the Wesleyan Methodist Missionary Society, Five Volumes (The Epworth Press, London, 1921-1924).

91. See https://www.mormonnewsroom.org/facts-and-statistics/country/south-africa. For more on the history of the Latter-day Saints in South Africa, see (in addition to the works mentioned in note 44 above): Booker T. Alston, "The Cumorah Baseball Club : Mormon Missionaries and Baseball in South Africa," Journal of Mormon History, vol. 40, no. 3 (Summer 2014): 93-106; R. Val Johnson, "South Africa: Land of Good Hope," Ensign, 1993, pp 32-42; Dean H. Garrett and Julie D. Heaps, "South Africa Celebrates 150 years," Church News, September 6, 2003; "South Africa," in Encyclopedia of Latterday Saints History, eds. Arnold K. Garr, Donald Q. Cannon, and Richard O. Cowan (Salt Lake City: Deseret Book, 2000), pp 1160-61. The author of this article is currently editing the entire Autobiography of Eli Wiggill, titled, "The Life and Adventures of Mr. Eli Wiggill," to be published in 2020, the commemorative bicentennial year of the British settlement in South Africa. 
Garrett, D.H., "The Controversial Death of Gobo Fango", Utah Historical Quarterly, 57, 3, 1989.

Garr, A.K., Cannon, D.Q. and Cowan, R.O. (eds), "South Africa", in Encyclopedia of Latter-day Saints History (Salt Lake City, Deseret Book, 2000).

Garrett, D.H. and Heaps, J.D., "South Africa Celebrates 150 Years", Church News, 6 September 2003.

Hewson, L. A., An Introduction to South African Methodist (The Standard Press, Cape Town, 1952).

“Homer Duncan Company (1861)”, at https://history.lds.org/overlandtravel/ companies/43/homer-duncan-company-1861 Accessed 1 June 2018.

Johnson, R.V., "South Africa: Land of Good Hope”, Ensign (1993).

"Kaffir: Racial Slur Used in Africa to Describe Indigenous African People", 15 November 2012, at http://originalpeople.org/kaffir-racial-slur-used-in-africato-describe-indigenous-african-people/ Accessed 31 May 2018.

"LDS Statistics and Church Facts, Total Church Membership, South Africa", at https://www.mormonnewsroom.org/facts-and-statistics/country/south-africa

Monson, F.R., "History of the South African Mission of the Church of Jesus Christ of Latter-day Saints", Master's thesis, Brigham Young University, 1971.

Mostert, N., Frontiers: The Epic of South Africa's Creation and the Tragedy of the Xhosa People (Alfred A. Knopf, New York, 1992).

Peires, J.B., The Dead Will Arise: Nongqawuse and the Great Xhosa Cattle-Killing Movement of 1856-7 (Ravan Press, Johannesburg, 1989).

Peterson, P.H., "The Mormon Reformation of 1856-1857: The Rhetoric and the Reality", Journal of Mormon History, 15 (1989).

"Port Elizabeth to Boston: 20 February 1861 to 19 April 1861", at https://mormonmigration.lib.byu.edu/mii/voyage/318?dateFrom=\&scandinavi

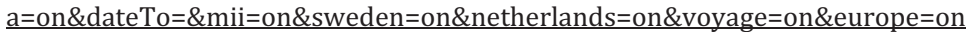
\&account $=$ on\&query=race+horse\&passenger $=$ on Accessed 1 June 2018.

Richards, J., Extract from a letter to his brother, "The Work in Hindostan: Extracts of Letters from Elders William Willes and Joseph Richards", Latter-day Saint Millennial Star, 14, 34(1852).

Thompson, L., A History of South Africa (Yale University Press, New Haven, 2001).

Whiteside, J., History of the Wesleyan Methodist Church of South Africa (Elliot Stock, London, 1906).

Wiggill, E., Eli Wiggill Missionary Report, December 1873, Church History Library, Salt Lake City, MS 6104.

Wiggill, E., The Life and Adventures of Mr. Eli Wiggill, in L. Tom Perry Special Collections, Harold B. Lee Library, Brigham Young University, MSS 9137.

Wiggill, I., Letter dated 23 October 1819, available at http://www.1820settlers.com/ (under 1820 Settlers Letters) Accessed 31 May 2018.

Wiggill, T.N., "Life of Isaac Wiggill and his Family", in The Cotswolds to the Cape: Isaac Wiggill 1820 Settler (Theo N. Wiggill and Monash University, Victoria, 2012).

Wilson, M., "Co-Operation and Conflict: The Eastern Cape Frontier", in M. Wilson and L. Thompson (eds), A History of South Africa to 1870 (Westview Press, Boulder, 1983). 
"Winterberg Eastern Cape", available online at en.wikipedia.org/wiki/Winterberg Accessed 1 June 2018.

Woods, F.E., "East to West through North and South: Mormon Immigration to and through America during the Civil War", BYU Studies, 39, 1 (2000).

Wright, E.P., A History of the South African Mission, 1852-1970, 3 volumes (19771986). 